International Journal of Agriculture and Environmental Research

ISSN: 2455-6939

Volume: 06, Issue: 02 "March-April 2020"

\title{
EFFECT OF SOWING DATES ON RICE (Oryza sativa L.) YIELD AND YIELD COMPONENTS OF (BHUR KAMBJA-1) VARIETY AT SOUTHERN BHUTAN
}

\author{
${ }^{1 *}$ Ngawang, ${ }^{2}$ Chezang Dendup \\ ${ }^{1}$ Agriculture Research and Development Center, Samtenling, Department of \\ Agriculture, Ministry of Agriculture and Forests, Thimphu, Bhutan. \\ ${ }^{1,2}$ Field crops sector, ARDC Samtenling \\ *Corresponding Author
}

DOI: 10.46609/IJAER.2020.v06i02.005 URL: https://doi.org/10.46609/IJAER.2020.v06i02.005

\begin{abstract}
Generally, rice is sown late March-April in high altitudes, early May-June in mid altitudes and June-early July in low altitudes in Bhutan. Sowing times of rice in Bhutan are often driven by the monsoon and are frequently delayed with no specific varieties developed for delayed sowing. Thus, the research was conducted at ARDC-Samtenling research station in 2017 to study effect of sowing dates on performance of widely adopted Bhur Kambjal rice variety to identify zonal specific optimum sowing window. Field experiment was laid out in a randomized complete block design with three replications having net plot size of $5 \times 2 \mathrm{~m}$. Experiment comprised of five different sowing dates that are $30^{\text {th }}$ May, $14^{\text {th }}$ June, $29^{\text {th }}$ June, $14^{\text {th }}$ July and $29^{\text {th }}$ July at an interval of 15 days. Some agronomical traits such as plant height, days to maturity, number of productive tillers per hill, panicle length at harvest and grain yield were measured and analyzed. The result indicated that effect of sowing dates on plant height, days to maturity, panicle length and grain yield were statistically significant at 0.05 probability level while number of productive tillers per hill showed no significant differences among different dates of sowing. Sowing at $30^{\text {th }}$ May and $14^{\text {th }}$ June resulted significantly higher yield of $3.53 \mathrm{t} \mathrm{ha}^{-1}$ and $3.40 \mathrm{t} \mathrm{ha}^{-1}$ respectively. The findings revealed that sowings at $29^{\text {th }}$ June, $14^{\text {th }}$ July and $29^{\text {th }}$ July yielded low of $2.37 \mathrm{t} \mathrm{ha}^{-1}, 2.97 \mathrm{t} \mathrm{ha}^{-1}$ and $2.83 \mathrm{t} \mathrm{ha}^{-1}$ respectively. This elucidates that late sowing and transplanting cause yield reduction which could not be recommended among farmers.
\end{abstract}

Keywords: Sowing time; Growth stages; Grain yield; Rice variety; Temperature

\section{INTRODUCTION}


International Journal of Agriculture and Environmental Research

ISSN: 2455-6939

Volume: 06, Issue: 02 "March-April 2020"

Rice is the primary staple for more than half the world's population with Asia as the largest consuming region (USDA, 2019). Like any other Asian country, rice is the most preferred staple food in Bhutan and the country accords top priority in increasing rice production for food security and rice self-sufficiency (Dendup et al., 2018). Rice in Bhutan is grown from tropical lowland (200 masl) to elevation as high as 2700 masl (Ghimiray et al., 2013) in the north commanding total area of 51,368 acres (DOA, 2017). However, the country is only $47 \%$ selfsufficient in rice and imports bigger chunks of rice requirement from India. Annual import of rice is increasing as revealed through import of 42,554 MT of rice in the first half of 2019 which was $12 \%$ increase compared to the same period in 2018 (RSD, 2019). This situation calls for interventions and study of our production technologies to increase rice productivity in the country.

Southern Bhutan makes up 35\% of national rice acreage under wet subtropical rice production zone and includes districts of Samdrupjongkhar, Samtse and Sarpang. The area is characterized by nutrient poor soil (low $\mathrm{N}$ and $\mathrm{K}$ ) compared to other region (Ghimiray et al., 2013) which also contributes to low rice productivity in the region. The lowland rice production ecology of Bhutan mostly depend on monsoon with weak assured irrigation facilities. In 2017, these three districts expressed mean productivity of $1488 \mathrm{~kg} / \mathrm{acre}$ against national average productivity of 1682 $\mathrm{kg} / \mathrm{acre}$ (DOA, 2017). Therefore, ARDC (Agriculture Research and Development Centre), Samtenling mandated with enhancing rice productivity in southern Bhutan strives to refine production package of rice through various research studies and finding optimum sowing window was one of them.

Rice in Bhutan is sown at different times in different locations based on rice environment and altitudes. Generally, in high altitudes paddy nursery is kept in late March-April, early May-June in mid altitudes and June-early July in low altitudes (Ghimiray et al., 2008). Rice sowing time sometimes get delayed due to lack of assured irrigation or surplus rainfall (Dawadi and Chaudhary, 2013) which such situation applies to the rice farming communities in Bhutan. Sowing time is a major factor in rice cultivation and indirectly determines soil temperature and weather conditions to which young seedlings and rice plants are exposed to during different development stages (Wani et al., 2018). Sowing time of rice therefore, is very important for optimum production mainly for three major reasons. According to (Farrell et al., 2003), these reasons are: (a) it ensures that vegetative growth occurs during periods of satisfactory temperatures and high levels of solar radiation. (b) The optimum sowing time for each cultivar ensures the cold sensitive stage occurs when the minimum temperatures are historically the warmest. (c) Sowing time guarantees that grain filling occurs when milder autumn temperatures are more likely, hence good grain quality is achieved. 
Further, (IRRI, 2015) guides to maintain proper planting time of rice as timely sown rice helps to produce fast-growing, uniform crop growth that will have higher yields and will better be able to compete with weeds and pests. However, the best time to plant depends on locality, variety, water availability, and the best harvest time. Study by (Huang et al., 2013) found out the existence of genotypic variation and efficacy of sowing time adjustments as useful management strategy to cope with temperature stress in warmer ecosystems. Therefore, study to find the precise sowing time for crops will be adaptive strategy under changing climate. Such information on rice varieties for wet-subtropical ecological zone in southern Bhutan is very limited which necessitated to undertake this study and have a scientific data established.

Based on above importance, this study was carried out at ARDC Samtenling with the objectives to (1) find out performance of the popularly grown Bhur Kambja-1 rice variety under different sowing dates and (2) to identify optimum sowing window for widely adopted improved variety (Bhur Kambja-1) in southern Bhutan.

\section{MATERIALS AND METHODS}

\subsection{Study site}

The study was conducted at Agriculture Research and Development Centre (ARDC), Samtenling from the period of May to December 2017 under irrigated condition. The experimental site is located at Sarpang Dzongkhag (district) of southern Bhutan lying at $26^{0} 54^{\prime}-26^{\prime} \mathrm{N}$ latitude and $90^{0} 25^{\prime}-26^{\prime}$ E longitude with an elevation of 375 meter above sea level (masl). The area falls under wet-subtropical agro-ecological zone of Bhutan by latitude ( $<600$ masl), temperature (Max $35^{\circ} \mathrm{C}$, Min $12^{\circ} \mathrm{C}$ ) and rainfall $(2500-5500 \mathrm{~mm})$. The mean of minimum and maximum temperature, sunshine hours, rainfall and relative humidity was recorded for three different main rice growth phases of vegetative, reproductive and ripening taking the IRRI standardized duration at 65,35 and 30 days, respectively for five different sowing dates (Table 1).

Table 1: Mean min and max temperature, rainfall, relative humidity, and sunshine hours during different stages of crop under study (NHCM 2017)

\begin{tabular}{lllllll}
\hline $\begin{array}{l}\text { Sowing } \\
\text { dates }\end{array}$ & Growth stages & $\begin{array}{l}\text { Average } \\
\text { Min temp } \\
\left({ }^{\circ} \mathrm{C}\right)\end{array}$ & $\begin{array}{l}\text { Average } \\
\text { Max temp } \\
\left({ }^{\circ} \mathrm{C}\right)\end{array}$ & $\begin{array}{l}\text { Average } \\
\text { sunshine } \\
(\mathrm{Hrs})\end{array}$ & $\begin{array}{l}\text { Average } \\
\text { rainfall }(\mathrm{mm})\end{array}$ & $\begin{array}{l}\text { Average } \\
\mathrm{RH}\end{array}$ \\
\hline \multirow{3}{*}{$30-$ May } & Vegetative & 24.2 & 29.4 & 2.08 & 33.98 & 90.29 \\
& Reproductive & 24.0 & 28.6 & 1.73 & 63.23 & 93.17 \\
& Ripening & 23.2 & 28.7 & 2.58 & 25.04 & 90.23 \\
\hline
\end{tabular}


International Journal of Agriculture and Environmental Research

ISSN: 2455-6939

Volume: 06, Issue: 02 "March-April 2020"

\begin{tabular}{lllllll}
\hline \multirow{3}{*}{ 14-Jun } & Vegetative & 24.2 & 29.0 & 1.35 & 44.96 & 91.55 \\
& Reproductive & 23.8 & 29.2 & 2.53 & 40.05 & 91.51 \\
& Ripening & 23.2 & 29.6 & 5.22 & 13.90 & 83.76 \\
\hline \multirow{2}{*}{ 29-Jun } & Vegetative & 24.4 & 29.4 & 2.03 & 46.69 & 90.98 \\
& Reproductive & 23.3 & 28.6 & 2.36 & 30.63 & 91.17 \\
& Ripening & 21.6 & 28.9 & 7.13 & 03.24 & 76.96 \\
\hline \multirow{3}{*}{ 14-Jul } & Vegetative & 24.2 & 29.3 & 2.20 & 46.09 & 91.18 \\
& Reproductive & 23.4 & 29.7 & 4.88 & 13.47 & 84.62 \\
& Ripening & 19.2 & 28.0 & 7.89 & 01.64 & 72.73 \\
\hline \multirow{2}{*}{ 29-Jul } & Vegetative & 23.8 & 28.8 & 1.76 & 48.99 & 92.33 \\
& Reproductive & 21.7 & 28.9 & 6.98 & 02.89 & 77.80 \\
& Ripening & 17.8 & 27.7 & 8.59 & 00.04 & 71.70 \\
\hline
\end{tabular}

\subsection{Design}

The experiment was laid in Randomized Complete Block Design (RCBD) with three replications and five levels of sowing dates. Size of each experimental unit was $10 \mathrm{~m}^{2}(5 \mathrm{~m} \times 2 \mathrm{~m})$ with spacing of $20 \mathrm{~cm}$ hill to hill and row to row. Sowing dates were staggered at an interval of 15 days and transplantation at 21 days interval (Table 2).

Table 2: Staggered sowing and transplanting dates

\begin{tabular}{llll}
\hline Date of seed sowing & Date of transplanting & $\begin{array}{l}\text { Staggered sowing duration } \\
\text { (Days) }\end{array}$ & $\begin{array}{l}\text { Staggered transplant } \\
\text { duration (Days) }\end{array}$ \\
\hline 30 May & $20 \mathrm{Jun}$ & 15 & 21 \\
$14 \mathrm{Jun}$ & $05 \mathrm{Jul}$ & 15 & 21 \\
$29 \mathrm{Jun}$ & $20 \mathrm{Jul}$ & 15 & 21 \\
$14 \mathrm{Jul}$ & $06 \mathrm{Aug}$ & 15 & 21 \\
$29 \mathrm{Jul}$ & $19 \mathrm{Aug}$ & 15 & 21 \\
\hline
\end{tabular}

\subsection{Intercultural Operation}


International Journal of Agriculture and Environmental Research

ISSN: 2455-6939

Volume: 06, Issue: 02 "March-April 2020"

Recommended dose of fertilizer at 70:40:30 NPK kg/ha was applied in the form of urea, Single Super Phosphate (SSP) and Muriate of Potash (MoP), respectively. Nitrogen fertilizer was applied in three split doses of $50 \%$ as basal, $25 \%$ at active tillering stage and $25 \%$ at panicle initiation. Puddling was carried out three days before each transplantation. Two hand weeding; day before first top dressing and a day before second top dressing was doen. No incidence of diseases and pest was recorded during the period of the study.

\subsection{Data collection}

Data on agronomical attributes such as plant height, productive tillers per hill, panicle length and days to maturity was collected at maturity before harvesting. Grain yield was determined from harvested area of $5.04 \mathrm{~m}^{2}$ adjusting moisture content to $14 \%$ using standard formula;

$$
\operatorname{Grain~Yield~}(t / h a)=\frac{\text { Adjusted moisture } \times \text { Plot Yield }(\mathrm{kg}) \times 10000}{\text { Plot size } \times 1000}
$$

Where Adjusted moisture $=\frac{100-M C}{100-86}$, and $\mathrm{MC}=$ grain moisture content at harvest.

All data collection was performed after discarding two rows plants from each side of the experimental unit to avoid biasness through border effect and was compiled in Microsoft excel spread sheet. The analysis of variance (ANOVA) at $\mathrm{P} 0.05$ level of significance for the comparison of treatment means was performed using statistical software 'STAR 2.0.1.'

\section{RESULTS AND DISCUSSION}

\subsection{Plant height}

The variety expressed differences in terms of plant height ( $\mathrm{p}=0.0105)$, however, the significant difference lie only between last sowing (29 July) and other sowing dates. The height ranged from $98.06 \mathrm{~cm}$ to $114.73 \mathrm{~cm}$ (Fig 1) with $4.15 \%$ coefficient of variance. The height of plant shows no statistical significant differences among sowing dates other than 29 July. The height of variety shows decreasing trend with further delayed sowing (14 July and 29 July) in agreement with (Metwally et al., 2012) who reported decreased plant height due to delayed sowing in two rice growing seasons under Egyptian condition. The similar findings were also reported by (Safdar et al., 2013), (Begum et al., 2018), (Walia et al., 2014) and (Ferrari et al., 2018). 


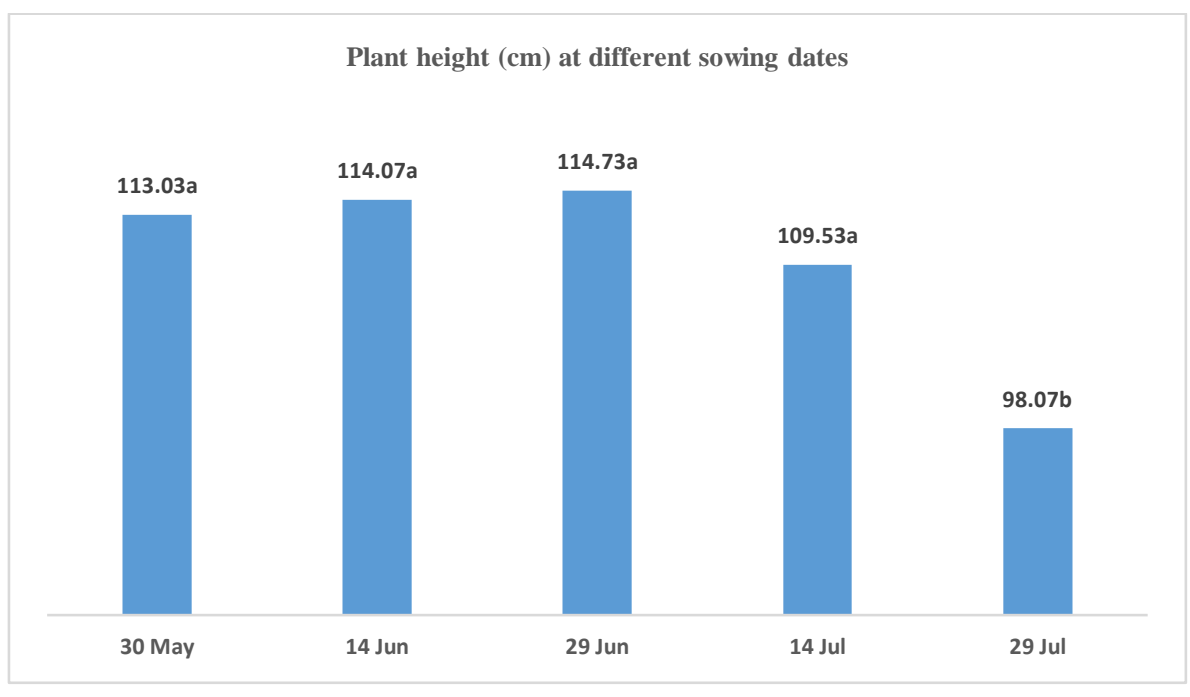

Fig 1: Plant height $(\mathrm{cm})$ under different time of sowing

\subsection{Days to maturity}

The sowing time influences maturity days significantly $(\mathrm{P}=0.0000, \mathrm{CV}=0.5082 \%)$. The variety matures at earliest (127 days) that was sown on 29 June (Table 3). It took equal 132 days to mature when sown on 30 May and 14 Jul, while it took a day more when sown on 14 Jun. When the variety is sown late $(29 \mathrm{Jul})$, the days to maturity prolonged to 136 days in accordance with the findings of (Rani, A.B. and Maragatham, N., 2013). Sowing dates 30 May, 14 Jun and 14 Jul showed statistically similar days to maturity with crop taking 132, 133, 132 days to mature (Table 3).

\subsection{Number of productive tillers per hill}

The number of productive tillers showed no significant differences among the different sowing time (Table 3) conforming to the findings (Iwuagwu et al., 2017) who reported no statistical significant differences in number of tillers under four levels of planting dates. However, the number ranged from 8.58 to 10.27 corresponding to sowing done on 14 Jul and 29 Jul, respectively. The highest number of tillers was recorded in the one that was sown on 29 Jul (late sowing) in contradiction to the findings of (Akbar et al.2010) and (Metwally et al.2012) who reported decrease tiller numbers with delayed sowing.

\subsection{Panicle length}

The panicle length at the time of harvest exhibits significant difference over the sowing times (Table 3). The seed that was sown on 29 Jul has slightly longer panicle length $(25.13 \mathrm{~cm})$ than the one sown on 30 May $(23.73 \mathrm{~cm})$ which are statically similar. The crop sown on 30 May, 29 
International Journal of Agriculture and Environmental Research

ISSN: 2455-6939

Volume: 06, Issue: 02 "March-April 2020"

Jun and $14 \mathrm{Jul}$ resulted statistically similar panicle length $(21.60 \mathrm{~cm}),(22.27 \mathrm{~cm})$, and $(21.40$ $\mathrm{cm})$, respectively. The coefficient of variation for this trait is $4.47 \%$. The trend of panicle length under this study showed longer length in early (30 May) and late sowings (29 Jul).

\subsection{Grain Yield}

The grain yield of Bhur Kambja1 sown over five different times revealed significant differences ( $\mathrm{P}$-value $=0.0003$ ). The yield ranged from $2.37 \mathrm{t} \mathrm{ha}^{-1}$ to $3.53 \mathrm{t} \mathrm{ha}^{-1}$ corresponding to the dates sown on 29 Jun and 30 May, respectively (Table 3). The yield from the date sown on 30 May and 14 Jun are statistically similar while the yield for the dates sown on 14 Jul and 29 Jul showed no significant differences. However, the crop sown on 29 Jun yielded the lowest $\left(2.37 \mathrm{t} \mathrm{ha}^{-1}\right)$ among all different dates of sowing. The general trend of decreasing yield was noticed with delayed sowing in good harmony with findings of (Akbar et al., 2010), (Faghani et al., 2011), (Metwally et al., 2014) and (Khalifa et al., 2014) who reported reduction in yield with delayed sowing.

\subsection{Grain yield components}

Plant height is important yield component and within certain range, (Zhang et al., 2017) found that the plant height is positively correlated to yield in rice. Moderate plant height is basis for the breeders. In the context of Bhutan, plant height plays major role in adoption of variety by farmers as straw yield is important cattle feed (Chhogyel et al., 2015) in the following dry months. Plant height over $100 \mathrm{~cm}$ was found acceptable in Bhutan (Ghimiary et al., 2008) which is expressed by Bhur Kambja-1 in four sowing times (30 May, 14 Jun, 20 Jun and 14 Jul) under study. The sowing done on 30 May and 14 Jun are recommendable as the test variety attains longer height of $113.03 \mathrm{~cm}$ and $114.06 \mathrm{~cm}$ (Fig 1), respectively with corresponding high yield. The reduced plant height in delayed sowings (14 July and 29 July) is attributed to the low temperature range during growth of the crop. It was reported by (Oh-e et al., 2007) that the rise in temperature increased plant height within the range of $30-35^{\circ} \mathrm{C}$. Similar findings were also made by (Osada et al., 1973). In the case of this study, the temperature ranges from $22-29{ }^{\circ} \mathrm{C}$ and 21.1-28.4 ${ }^{\circ} \mathrm{C}$ in the crop sown on $14 \mathrm{Jul}$ and $29 \mathrm{Jul}$ respectively which are lower range than other dates of sowing. This could have contributed to reduced plant height. It was also found out by (Hirai et al, 1993) that nitrogen uptake in rice plant grown under 90\% RH (Relative Humidity) was higher than those of rice grown under $60 \% \mathrm{RH}$. The reduced plant height in this study for the crop sown on $14 \mathrm{Jul}$ and $29 \mathrm{Jul}$ could be due to poor uptake of nitrogen and consequent reduction in plant heights as average $\mathrm{RH}$ for all sowing dates are in the order 30 May=91.23\%> $14 \mathrm{Jun}=88.7 \%>29 \mathrm{Jun}=86.37 \%>14 \mathrm{Jul}=82.8 \%>29 \mathrm{Jul}=80.61 \%$.

The growth duration of a variety is highly location and season specific because of the interactions between the variety's photoperiod, temperature sensitivity and weather conditions 
International Journal of Agriculture and Environmental Research

ISSN: 2455-6939

Volume: 06, Issue: 02 "March-April 2020"

(Yoshida, 1981). The differences in days to maturity of variety under study could have been due to cultivar as the maturity in rice is more cultivar dependent than other cereals (Bruns, 2009). The crop sown on 29 Jul took significantly about a week more resonating with findings of (Rani, A.B. and Maragatham, N., 2013) who reported the reduction in crop duration under prolonged low temperature. This might be due to high temperature helping the crop in attaining phonological stages earlier than low temperature periods. A review on impact of weather on rice also asserts that at lower temperature, translocation of photosynthates to grain took place at a slower rate and thus maturity days get delayed (Sridevi, V. and Chellamuthu, V., 2015). This could be the reason for delayed maturity for the crop sown on 29 Jul. However, the crop sown on 29 Jun took only 127 days to mature and this may be favorable accumulated effect variety, temperature, radiation and $\mathrm{RH}$.

The tillering ability is one of the traits which determines yield and it is considered to be a varietal character with partial environmental influence (Nuruzzaman et al., 2000). The highest number of tillers in the crop sown on $29 \mathrm{Jul}$ is attributed to favorable environmental conditions which exploited tillering ability of Bhur kambja-1. However, the corresponding yield of the crop sown on $29 \mathrm{Jul}$ is not the highest which might be due to high mortality rate of tillers at reproductive phase. The grain filling in late sowing was found poor by (Dawadi and Chaudary, 2013) which might have contributed to low yield of the crop sown on 29 Jul despite more number of tiller. The non-significant differences between different dates of sowing may be due to some environmental effect as temperature, light intensity and nutritional condition also affect tillering in rice.

Panicle length differs significantly in different dates of sowing and highest length $(25.13 \mathrm{~cm})$ was achieved in the crop sown on $29^{\text {th }}$ July. (Begum et al., 2018) found reducing trend in the length of panicle in late sowings, but the average temperature in their case was increasing. The average temperature in this study decreases in each staggered sowing, hence, our findings agree that the panicle length appears long in bit lower temperature.

\subsection{Grain yield}

The yield of early sown (30 May and 14 Jun) crop are significantly higher than rest of the sowing dates probably due to favorable weather conditions such as rainfall and temperature during critical stages of crop development. According to (Jagtap et al., 2017), the environmental factors like temperature and humidity are most favorable for grain development in early transplanting as compared to late transplanting. This maybe the reason for higher yield resulted from the crop sown on 30 May and 14 Jun. The crop sown on 29 Jul despite longer panicle length and highest number of productive tillers showed second lowest yield of $\left(2.83 \mathrm{t} \mathrm{ha}^{-1}\right)$ only. This may be due to coincidence of reproductive stage of the crop with low temperature range. According to 
(Yoshida, 1981), the optimum temperature for flowering is $30-33{ }^{\circ} \mathrm{C}$, while the reproductive stage of the crop sown on $29 \mathrm{Jul}$ coincided with the temperature range of $21.7-28.9{ }^{\circ} \mathrm{C}$. This could have induced spikelet sterility as cool weather causes sterility by interfering with pollen grain formation (Sridevi, V. and Chellamuthu, V., 2015). Further, the low yield recorded from the crop sown on 29 Jun and 14 Jul could be due to similar condition. The low yields in delayed sowing can also be attributed to the photoperiod of according to the fact that rice is considered short-day and summer crop.

Table 3: Agronomic traits and yield of Bhur Kambja1 under different time of sowing

\begin{tabular}{lllll}
\hline Sowing time & $\begin{array}{l}\text { Days to maturity } \\
\text { (No.) }\end{array}$ & $\begin{array}{l}\text { Number of Productive } \\
\text { tillers hill }{ }^{-1}\end{array}$ & $\begin{array}{l}\text { Panicle length at } \\
\text { harvest }(\mathrm{cm})\end{array}$ & $\begin{array}{l}\text { Yield } \\
\text { hectare }^{-1}\end{array}$ \\
\hline 30 May & $132 \mathrm{~b}$ & 10.00 & $23.73 \mathrm{ab}$ & $3.53 \mathrm{a}$ \\
14 Jun & $133 \mathrm{~b}$ & 9.13 & $21.60 \mathrm{c}$ & $3.40 \mathrm{a}$ \\
29 Jun & $127 \mathrm{c}$ & 9.53 & $22.27 \mathrm{bc}$ & $2.37 \mathrm{c}$ \\
14 Jul & $132 \mathrm{~b}$ & 8.58 & $21.40 \mathrm{c}$ & $2.97 \mathrm{~b}$ \\
29 Jul & $136 \mathrm{a}$ & 10.27 & $25.13 \mathrm{a}$ & $2.83 \mathrm{~b}$ \\
P-value & 0.0000 & 0.5830 & 0.0092 & 0.0003 \\
CV (\%) & 0.5082 & 14.51 & 4.47 & 6.06 \\
SE & 0.5477 & 1.13 & 0.8324 & 0.1495 \\
\hline
\end{tabular}

In a column, same letter shows non-significant and different letter shows significant differences among the treatments

\section{RECOMMENDATION AND CONCLUSION}

The conclusion drawn from this study is that, the sowing dates significantly influences yield, plant height, panicle length and days to maturity of Bhur Kambja-1. The result indicated that Bhur Kambja-1 in Southern Bhutan sown over last week of May extending to mid-June gives high yield while the yield decreases if sowing is delayed beyond July.

The farmers adopting Bhur Kambja-1 in southern Bhutan under wet-subtropical zone may consider this as optimum sowing window. However, this result may not to imply to other varieties as findings of significant interaction between sowing time and rice varieties was reported by (Fagahni et al.,2011), (Safdar et al., (2013), (Khalifa et al. 2014), and (Meirelles et al. 2019). However, farmers with no assured irrigation may adopt Bhur Kambja-1 in times of delayed monsoon with expected yield reduction reported in this study. 
International Journal of Agriculture and Environmental Research

ISSN: 2455-6939

Volume: 06, Issue: 02 "March-April 2020"

\section{ACKNOWLEDGEMENTS}

The authors are indebted to farm attendants and field crops colleagues of ARDC Samtenling for their support in establishing the trial. We also like to thank all researchers at ARDC Samtenling for their valuable comments and help during the study.

\section{REFERENCES}

Akbar, N. Iqbal, A., Khan, H. Z., Hanif, K. and Bashir, M. U. (2010). Effect of different sowing dates on the yield and yield components of direct seeded fine rice (Oryza sativa L.). Journal of Plant Breeding and Crop Science. 2(10), 312-315.

Begum, S. Rahman, M. H., Nasif, S.O. and Ahamed, K.U. (2018). Effect of Sowing Dates on Some Morpho-physiological Traits of an Exotic (China) Hybrid Rice Variety in Bangladesh. Journal of Agriculture and Ecology Research International. 15(2), 1-10.

Bruns, H.A. (2009). A Survey of Factors Involved in Crop Maturity. Agronomy Journal. 101(1), 60-66.

Chhogyel, N., Pradhan, N., Ghimiray, M. and Bajgai, Y. (2015). Evaluation of short duration rice (Oryza sativa) varieties as a strategy to cope with climate change. In Proceedings of Bhutan Ecological Society (2015): Thimphu, Bhutan.

Dawadi, K. P. and Chaudhary N.K. (2013). Effect of sowing dates and varieties on yield and yield attributes of direct seeded rice in Chitwan condition. The Journal of Agriculture and Environment. Vol: 14, 121-130.

Dendup, C., Ngawang N. and Chhogyel, N. (2018). Effects of different planting methods on rice (Oryza sativa L.) crop performance and labor cost comparison. Bhutanese Journal of Agriculture. 1(1), 13-22.

DOA (Department of Agriculture). (2017). Bhutan RNR Statistics. Ministry of Agriculture and Forests. Thimphu Bhutan.

Farrell, N. K., Fox, R. L., Williams, S.F. and Lewin, L.G. (2003). Avoiding low temperature damage in Australia's rice industry with photoperiod sensitive cultivars. In Proceedings of the $11^{\text {th }}$ Australian Agronomy Conference. Deakin University, Geelong, Feb (2-6), Victoria, Australia.

Ferrari, S., Pagliari, P. and Trettel, J. (2018). Optimum Sowing Date and Genotype Testing for Upland Rice Production in Brazil. Scientific Reports. 8:8227. DOI: 10.1038/s41598-01826628-6. 
International Journal of Agriculture and Environmental Research

ISSN: 2455-6939

Volume: 06, Issue: 02 "March-April 2020"

Faghani, R., Mobasser, H.M., Dehpor, A.A and Tavakkoli, K. (2011). The effect of planting date and seedling age on yield and yield components of rice (Oryza sativa L.) varieties in North of Iran. African Journal of Agricultural Research. 6(11), 2571-2575.

Ghimiray, M., Dorji, K.D., Katwal, T.B., Penjore, U., Dorji, S., Pem, S., Tenzin G. and Pradhan, K. (2008). Rice in Bhutan- A Source Book. CoRRB (Council for RNR Research of Bhutan). Ministry of Agriculture. Thimphu:Bhutan. 47p.

Ghimary, M, Pandey, S. and Velasco, M.L. (2013). Estimating adoption rate of modern varieties in Bhutan. Tracking Improved Varieties in South Asia. Bhutan Report on Rice. Retrieved from http://rcbajo.gov.bt/wp-content/uploads/2016/03/Rice-Adoption-Report.pdf

Hirai, G.I., Chiyo, H., Tanaka, O., Hirano, T. and Omori M. (1993). Studies on effect of relative humidity of atmosphere on growth and physiology of rice plants. VIII. Effect of ambient humidity on dry mater production and nitrogen absorption at various temperatures. Japanese J Crop Sci. 62(3), 395-400.

Huang, J., Zhu, L., Shah, F., Nie, L., Cui, K., Shah, T., Wu, W., Chen, Y., Chen, C., Wang, Q. and Lian, Y. (2013). Efficacy of sowing date adjustment as a management strategy to cope with rice (Oryza sativa L.) seed quality deterioration due to elevated temperature. Australian Journal of Crop Science. 7(5), 543-549.

IRRI (International Rice Research Institute). (2015). Rice Production Manual. Los Banos, Phillipines. 11p.

Iwuagwu, C.C., Umechuruba, C.I. and Nwogbaga, A.C. (2017). Effect of Planting Date, Spacing and Seeding Methods on Disease Development and Yield Components of Rice (Oryza sativa L.) in South Eastern Nigeria. Journal of Agricultural Science and Technology. 7(2017), 100-113.

Jatap, D.N., Mahadkar, U.V. and Chavan S.A. (2017). Response of rice varieties to different sowing windows under Konkan conditions. Agric. Sci. Digest., 37(1), 78-80.

Khalifa, A.A.A., ELkhoby, W. and Okasha, E.M. (2014). Effect of sowing dates and seed rates on some rice cultivars. African Journal of Agricultural Research. 9(2), 196-201.

Meirelles, F.C., Arf, O., Garcia, N.F.S., Takasu, A.T., Buzo, F.D.S., Corsini, D.C.D.C., Martins, J.T., Andrade, J.A.D. C. and Portugal, J.R. (2019). Australian Journal of Crop Science. 13(02), 242-250. DOI: 10.21475/ajcs.19.13.02.p1312 
International Journal of Agriculture and Environmental Research

ISSN: 2455-6939

Volume: 06, Issue: 02 "March-April 2020"

Metwally, T.F., El-Malky, M.M., Glelah, A.A., and Gharieb, A.S. (2012). Performance of Elite Aromatic Rice Under Different Sowing Dates Under Egyptian Condition. J. Plant Production. 3(2), 311-333.

Nuruzzaman, M., Yamamoto, Y., Nitta, Y., Yoshida, T. and Miyazaki, A. (2000). Varietal differences in tillering ability of fourteen japonica and indica rice varieties.Soil Science and Plant Nutrition. 46(2), 381-391.

Rani, A.B. and Maragatham, N. (2013). Effect of elevated temperature on rice phenology and yield. Indian Journal of Science and Technology. 6(8),

RNR Statistics Division. (20019). Statistics on import of major food items from India during JanJun 2019. DoA, MoAF, Thimphu, Bhutan.

Safdar, M.E., Noorka, I.R., Tanveer, A., Tariq, S.A. and Rauf, S. (2013). Growth and yield of advanced breeding lines of medium grain rice as influenced by different transplantation dates. The Journal of Animal and Plant Sciences. 23(1), 227-231.

Sridevi, V. and Chellamuthu,V. (2015). Impact of weather on rice-A review. International Journal of Apllied Research. 1(9), 825-831.

USDA, (2019).Rice Sector at a Glance. Retrieved from https://www.ers.usda.gov/topics/crops/rice/rice-sector-at-a-glance/

Walia, U.S., Wallia, S.S., Sidhu, A.S. and Nayar, S. (2014). Productivity of direct seeded rice in relation to different dates of sowing and varieties in Central Punjab. Journal of Crop and Weed. 10(1), 126-129.

Wani, S.A., Bhat, M.A. and Bhat, M.A. (2018). An overview on the significance of sowing dates and nitrogen fertilization on growth and yield of rice. International Journal of Chemical Studies. 6(20, 2640-2655.

Yoshida, S. 1981. Fundamentals of rice crop science. International Rice Research Institute. Los Banos, Philipines. 217-230p.

Zhang, Y., Yu, C., Lin, J., Liu, J., Liu, B., Wang, J., Huang, H. and Zhao, T. (2017). OsMPH1 regulates plant height and improves grain yield in rice. PLos ONE, 12(7). https://doi.org/10.1371/journal.pone.0180825 